
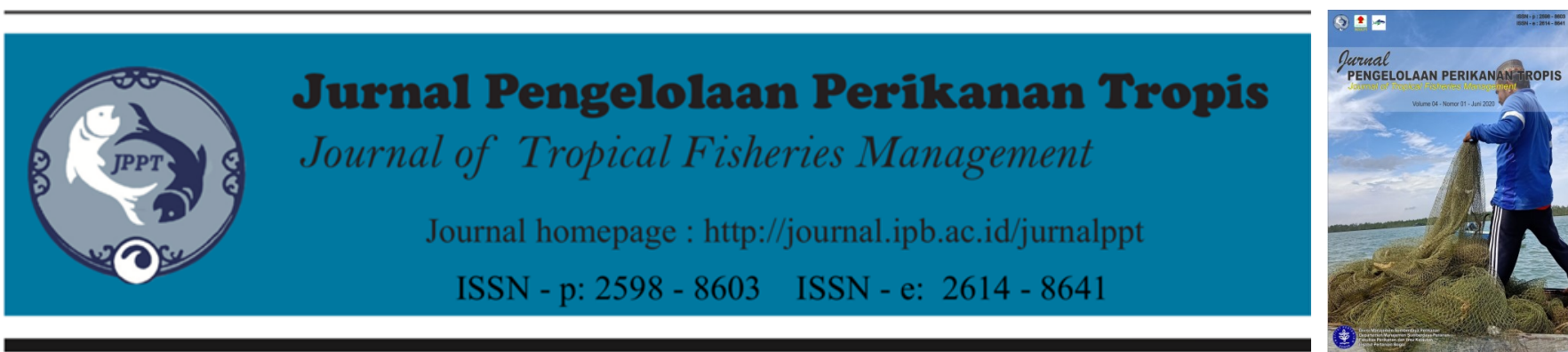

\title{
Pendekatan Agent Based Model (AMB) pada Perikanan Skala Kecil di Daerah Penangkapan Selat Sunda
}

\section{(Agent Based Model (ABM) Approach on Small Scale Fisheries in Sunda Strait Fishing Ground)}

\author{
Yonvitner $^{1,2^{*}}$, Nur Irsyam ${ }^{2}$, Achmad Fahrudin ${ }^{1}$, Rahmat Kurnia ${ }^{1}$ \\ ${ }^{1}$ Divisi Manajemen Sumberdaya Perikanan, Departemen Manajemen Sumberdaya Perairan, Fakultas Perikanan dan Ilmu \\ Kelautan. IPB University \\ ${ }^{2}$ Pusat Studi Bencana-Lembaga Penelitian dan Pengabdian Masyarakat - IPB University
}

\begin{tabular}{l}
\hline ARTIKEL INFO \\
\hline Article History \\
Recevied: 15 Mei 2020 \\
Accepted: 27 Juni 2020 \\
\hline Kata Kunci: \\
Agent Based Model, harga ikan, \\
musim tangkap, produksi, Selat Sun- \\
da \\
Keywords: \\
Agent Based Model, fishing season, \\
price fish, production, Sunda trait
\end{tabular}

Korespondensi Author

Yonvitner,

Divisi Manajemen Sumberdaya Perikanan, Departemen Manajemen Sumberdaya Perairan, Fakultas Perikanan dan Ilmu Kelautan. IPB University. Email:

yonvitr@yahoo.com \begin{abstract}
ABSTRAK
Prediksi musim dan tingkat pemanfaatan sumberdaya ikan di perairan Selat Sunda sangat penting untuk mengontrol eksploitasi yang berlebih. Untuk itu, pendekatan berbasis agen (agent based approach) dari perubahan musim dan faktor input lainnya terhadap perilaku nelayan perlu dikaji. Penelitian dilakukan di Lempasing dari nelayan yang menangkap di Selat Sunda dengan teknik purposive sampling terhadap nelayan agen (purse seine) dan nelayan non-agen (non purse seine) dengan software Poseidon 1.0. Pola musim penangkapan ikan pada musim timur, daerah penangkapan nelayan agen semakin lama akan semakin mengecil dikarenakan faktor alam dan juga kenaikan harga solar. Nilai produksi dari nelayan agen mengalami penurunan diakibatkan adanya ketidakseimbangan harga jual ikan. Pengaruh produksi terhadap pembentukan harga tidak terlalu berpengaruh dan relatif linier. Analisis agent based model memberikan gambaran strategi berupa pengaturan upaya penangkapan, konsumsi bahan bakar, dan pendapatan terhadap nelayan agen kaitannya dengan perubahan harga solar.
\end{abstract}

\section{ABSTRACT}

The assessment of season and level of fishing fish in the Sunda Strait waters are very important to control over-exploitation. For this reason, an agent-based approach to seasonal changes and other input factors on the behavior of fishermen need to be assessed. The study was conducted in Lempasing from fishermen who catch in the Sunda Strait with a purposive sampling technique for agent fishermen (purse seine) and non-agen fishermen (non-purse seine) with Poseidon 1.0 software. The pattern of fishing season in the east season, the area where fishing agents are getting smaller will be increasingly smaller due to natural factors and also rising diesel prices. The value of production from fishing agents has decreased due to an imbalance in the price of selling fish. The effect of production on price formation is not very influential and is relatively linear. Agent based model analysis provides a description of the strategy in the form of fishing effort management, fuel consumption, and income for fishermen agents related to changes in diesel prices.

\section{PENDAHULUAN}

Peningkatan pemanfaatan sumberdaya ikan hampir terjadi di semua wilayah perairan laut. Aktivitas penangkapan yang terjadi terus menerus dapat menurunkan sediaan stok ikan dan dapat mengarah pada eksploitasi. Untuk itu, sebuah mekanisme pemanfaatan yang mampu mengendalikan pemanfaatan penting dirancang. Dalam perikanan di Indonesia, ada dua faktor utama yang berperan dalam mengendalikan penangkapan yaitu musim dan perubahan kebijakan.

Musim menjadi dominan berpengaruh karena secara gradual menyebabkan aktivitas usaha penangkapan terhenti. Selanjutnya, kaitanya dengan kebijakan biasanya adalah faktor produksi, seperti harga bahan bakar dan harga jual ikan. Kedua faktor input dan output ini menjadi salah satu penentu bagi nelayan untuk menetapkan rencana penangkapan, lokasi, lama waktu dan target tangkapan lainya. Dalam riset agent based model (ABM) di Labuan dan Lempasing ini, pihak yang dipilih sebagai agen adalah nelayan. Semua informasi sebagai input kedalam model diperoleh dari nelayan. Studi ini kemudian memilih nelayan Lempasing yang menangkap ikan di Selat Sunda sebagai agen untuk mengetahui pola pergerakan dan rencana 
perubahan penangkapan dari berbagai faktor input dan output sebelumnya.

Hasil tangkapan nelayan Lempasing terdiri dari berbagai jenis ikan pelagis dan demersal. Jenis ikan hasil tangkapan yang dominan didaratkan adalah ikan tenggiri, kembung, bawal, tongkol, tembang, teri, dan lain-lain (Pujiani 2009), walaupun tidak sedikit juga jenis ikan lainnya yang tertangkap. Hasil tangkapan ini ada yang dilelang di tempat pelelang ikan (TPI) serta ada yang dijual langsung ke pembeli atau bakul yang ada di pelabuhan. Secara keseluruhan, aktivitas ini merupakan bagian dari proses pemasaran yang menjadi output usaha perikanan yang dipertimbangkan dalam penelitan berbasis agen.

Pemanfaatan sumberdaya ikan penting diketahui untuk memastikan dan mengontrol tingkat eksploitasi sehingga perlu kehati-hatian (Ardelia et al. 2017). Pertimbangan tingkat kelayakan usaha perikanan, data tentang musim dan waktu penangkapan ikan diperlukan untuk memastikan usaha penangkapan. Selain itu tingkat efektivitas dan efisiensi yang tinggi, dengan tidak menyebabkan kerusakan dan gangguan kelestarian sumberdaya ikan. Dengan demikian usaha perikanan tetap mampu memberikan keuntungan usaha dalam jangka panjang.

Selain karena pengaruh musim penangkapan, peningkatan output atau pendapat yang diawali dari peningkatan hasil tangkapan nelayan juga ditentukan oleh pengaruh input-input produksi yang menjadi modal penangkapan. Model berbasis agen menjadi salah satu alat yang saat ini berkembang dan banyak digunakan untuk memprediksi usaha penangkapan ikan dan budidaya (Rahmawan 2018), Sehingga dapat disiapkan perencanaan untuk proses penangkapan dan pengaturan kuota dan lokasi penangkapan. Kajian pendekatan berbasis agen yang dilakukan untuk menguji informasi dari agen terhadap simulasi dan model rencana usaha penangkapan yang dilakukan nelayan Lempasing yang menangkap di Selat Sunda.

\section{METODE}

\section{Waktu dan Lokasi Penelitian}

Penelitian dilakukan di Lempasing dengan lokasi agen di TPI Lempasing Lampung (Gambar 1) selama bulan September-Desember 2019. Data dikumpulkan, di antaranya koordinat lokasi penangkapan, volume produksi, dan biaya operasional (harga solar).

\section{Pengumpulan Data}

Nelayan yang ditetapkan sebagai agen adalah yang menggunakan alat tangkap purse seine dan lokasi penangkapan di perairan Selat Sunda. Nelayan agen dibekali GPS (Global Postioning System) sebagai penanda titik-titik yang menjadi lokasi penangkapan. Dari setiap lokasi penangkapan, data lainnya seperti hasil produksi dan biaya operasional (harga solar) dari kapal agen dicatat pada logbook setiap kali melaut. Data yang diperoleh diperkuat dengan data sekunder dari Laporan Statistik perikanan tangkap PPP Lempasing tahun 2009-2019 dan Dinas Perikanan Lampung.

\section{Analisis Data}

Kajian dalam musim penangkapan, selain informasi dari nelayan juga dilakukan analisis indeks musim penangkapan (IMP). Hasil

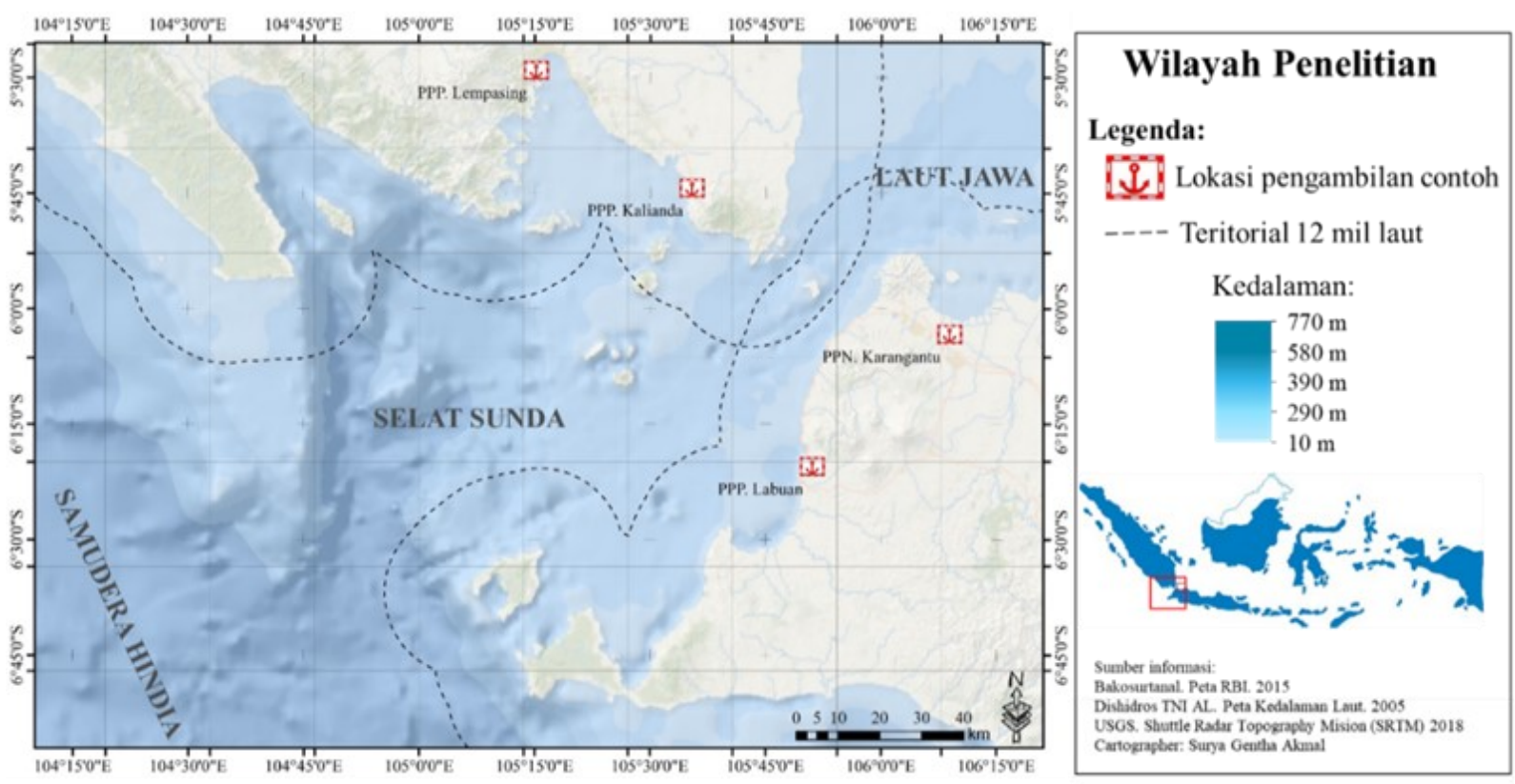

Gambar 1. Lokasi penelitian di PPP Lempasing dan Selat Sunda 
perhitungan indeks musim penangkapan setiap bulan dijadikan sebagai pertimbangan aktivitas nelayan. Indeks musim penangkapan ikan dapat dikategorikan menjadi tiga kategori berdasarkan nilai IMP, antara lain musim paceklik, sedang, dan puncak (Zulkarnain et al. 2012).

Analisis berbasis agen, paremeter input yang digunakan dalam mengkaji pola perubahan musim dan faktor input lainnya, seperti biaya operasional terhadap perilaku nelayan. ABM merupakan pendekatan pemodelan untuk analisis sistem yang kompleks (Ann et al. 2005) dalam lingkungan yang sesungguhnya (nyata). Menurut Health dan Hill (2010), ada tiga poin yang mendasari kehadiran pendekatan ini, yaitu (1) kehadiran dan perkembangan teknologi komputer, (2) kesadaran akan kebutuhan pentingnya mengkaji kompleksitas, dan (3) pemahaman akan penting pendekatan berbasis sistem.

Pemodelan berbasis agen menjadi metode pendekatan yang sangat baik untuk alternatif pemecahan masalah dalam sistem yang kompleks. Teknik ini juga dapat diaplikasikan pada sektor perikanan, termasuk mengkaji perilaku produksi nelayan dalam kaitannya dengan musim penangkapan dan biaya operasional. Selanjutnya, beberapa perlakukan diperlukan agar perilaku agen dapat dikontrol yang kemudian dijadikan input bagi model yang di simulasikan (Macal dan North 2010).

\section{HASIL DAN PEMBAHASAN}

Hasil

Hasil pengolahan data dan konfirmasi agen, pola musim penangkapan dievaluasi dari nelayan purse seine. Jenis-jenis ikan tangkapan antara lain ikan kembung, tongkol, dan cumi-cumi dan lainya. Pola musim penangkapan dan arah penangkapan kapal purse seine juga dipengaruhi oleh input produksi penangkap. Pola indek musim penangkapan nelayan purse seine selama 2019 ditampilkan Gambar 2.

Penangkapan pada bulan Januari, Februari, Maret, Juli, dan September tergolong dibawah normal atau tidak musim penangkapan. Bulan April, Mei, Juni, Agustus, Oktober, November, dan Desember terlihat musim penangkapan ikan. Keseluruhan nilai IMP tertinggi berada pada bulan April sebesar 136\% (musim puncak) terendah pada bulan Januari sebesar 52\% (musim paceklik). Nilai produksi intrinsic dari para agen juga mengkonfirmasi bahwa pada awal tahun tangkapan rendah karena pengaruh musim barat yang cukup kuat.

Selama 5 tahun terakhir, produksi tahun 2014 terlihat ada lonjakan hasil tangkapan dari tahun sebelum dan sesudahnya. Kemudian perlahan produksi kembali turun pada tahun 2019 yang disebabkan kurangnya pencatatan di TPI. Pola sebaran produksi dan nilai produksi selama 20092019 ditampilkan pada Gambar 3.

Tabel 1. Kriteria dari Musim Penangkapan

\begin{tabular}{ccc}
\hline No & Batasan Nilai IMP & Kategori Musim \\
\hline 1 & $<50 \%$ & Paceklik \\
2 & $50 \% \leq \mathrm{IMP}<100 \%$ & Sedang \\
3 & $\mathrm{IMP} \geq 100 \%$ & Puncak \\
\hline
\end{tabular}

Sumber: Zulkarnain et al. (2012)

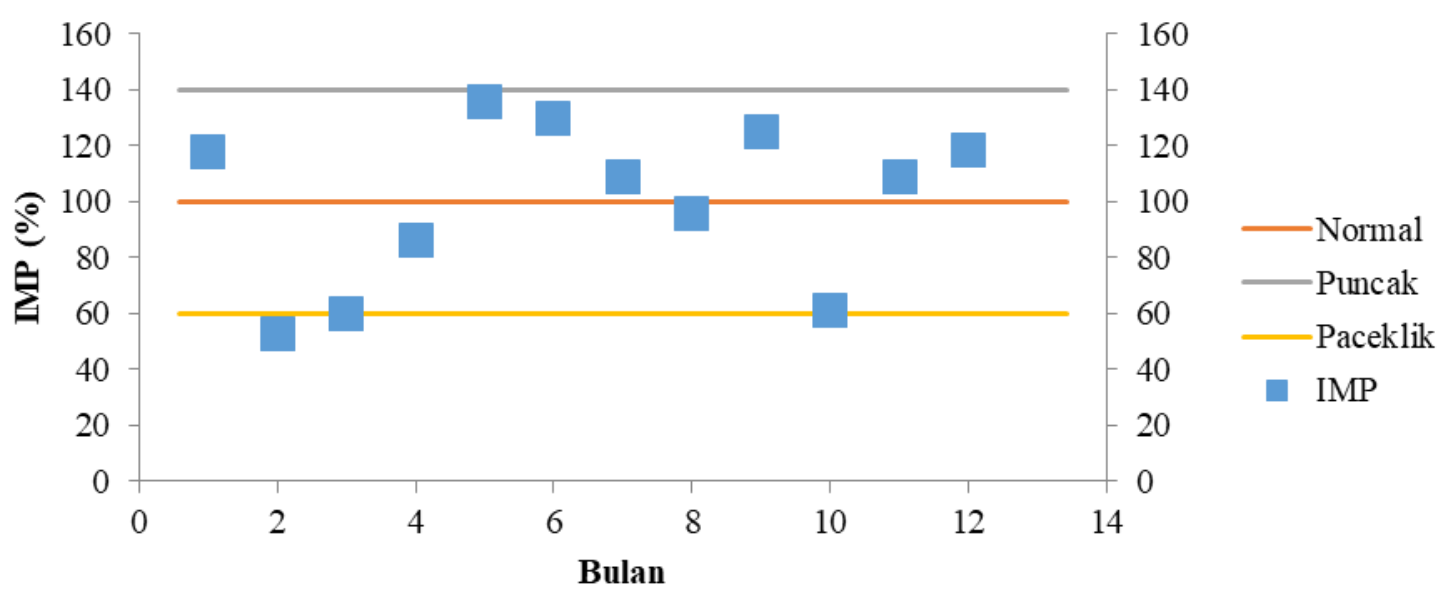

Gambar 2. Nilai Indeks Musim Penangkapan (IMP) Tahun 2019 
Volume produksi dan nilai produksi tangkapan mengalami fluktuasi setiap tahunnya. Akan tetapi antar produksi dan nilai produksi memiliki pola yang relatif linier. Secara umum, kenaikan produksi juga akan menyebabkan naiknya nilai produksi dan performance CPUE (Saul et al. 2007). Volume produksi dan nilai produksi tertinggi yang dihasilkan pada tahun 2014 mencapai 2101,3265 ton dan $\mathrm{Rp}$. $28.181,4034$ juta. Kegiatan penangkapan yang terus memacu peningkatan produksi dapat mendorong tingginya kerentanan ikan (Yonvitner et al. 2018).

Nelayan agen yang merupakan nelayan purse seine melakukan penangkapan secara eksploratif. Nelayan umumnya akan mencari-cari lokasi penangkapan sampai benar-benar ditemukan daerah fishing ground. Lokasi penangkapan adalah titik-titik lokasi yang menurut mereka sebagai daerah pusat penyebaran ikan dimana intensitas kemunculan ikan tinggi. Selain itu, operasi penangkapan ikan, tracking kapal akan lebih lama pada daerah fishing ground yang ditemukan tersebut .

Berdasarkan hasil observasi dari agen, koordinat penangkapan nelayan tersebar di daerah perairan Selat Sunda, di antaranya sekitar Pulau Tabuan, Legundi, Sabesi, dan Sebuku (Gambar 4). Adapun yang menjadi daerah penangkapan yang sering dikunjungi, yaitu daerah sekitar Pulau Legundi. Sekitar Pulau Legundi menjadi titik dengan trip kapal terbanyak ke daerah tersebut. Sebaran koordinat agen menunjukan bahwa daerah penangkapan nelayan berada dalam

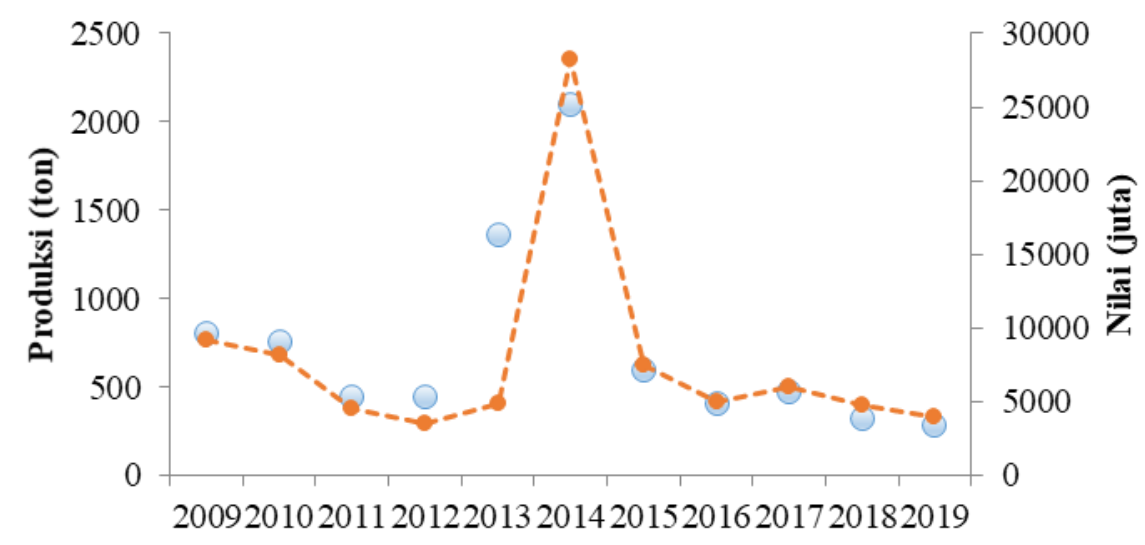

Tahun

- Productioni -----Value

Gambar 3. Pola volume dan nilai produksi PPP Lempasing
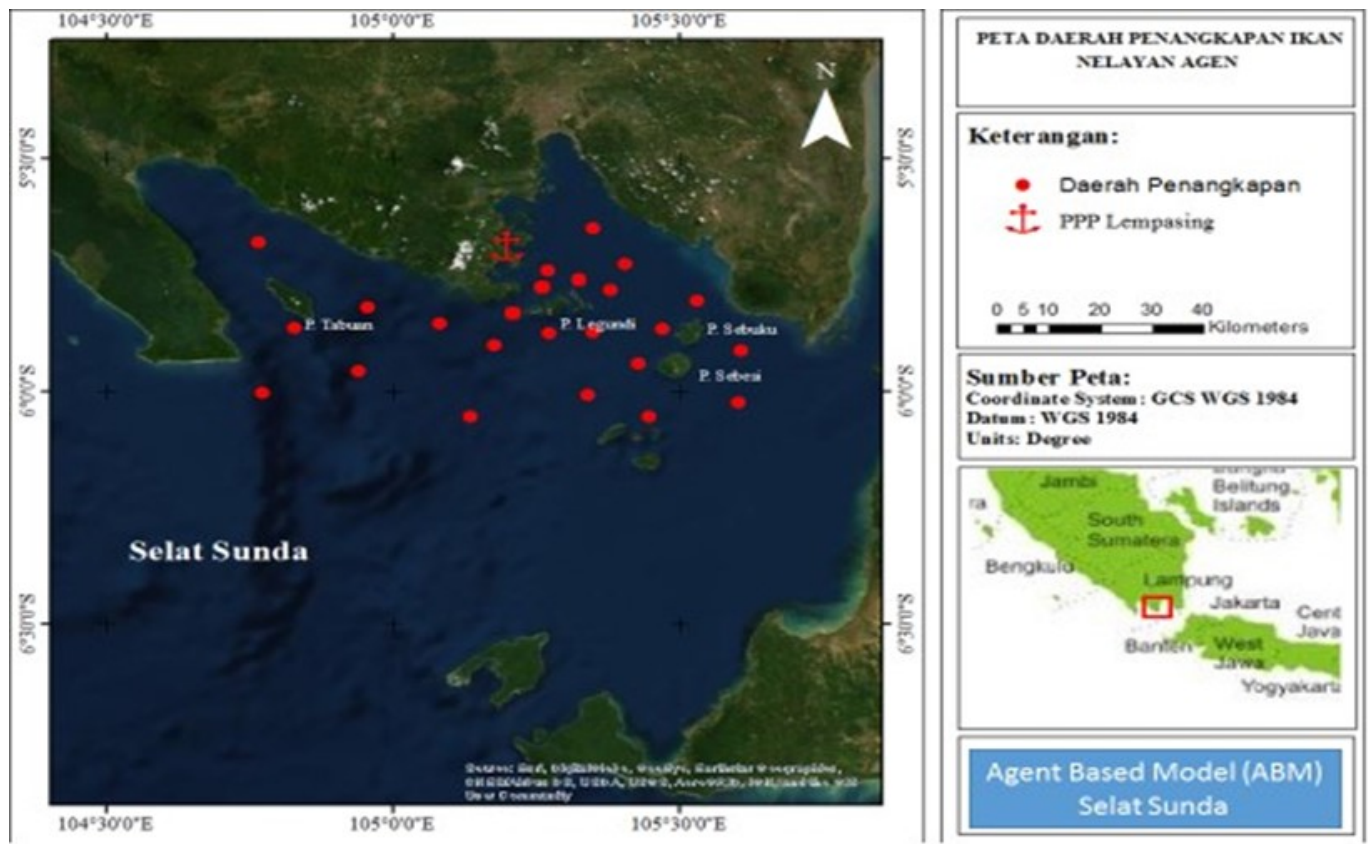

Gambar 4. Fishing ground dari kapal penangkapan ikan purse seine (agen) 
perairan Selat Sunda.

Skenario model berbasis agent dengan aplikasi POSEIDON 1.0 dilakukan pada data tahun 2015, 2016, 2017 2018, dan 2019. Skenario tahun 2015 dengan harga solar Rp 6.900, tahun 2016 dengan harga solar Rp 5.650, tahun 2017 dengan harga solar Rp 5.150, tahun 2018 dengan harga solar $\mathrm{Rp} 5.150$ dan tahun 2019 dengan harga solar Rp 9.800.

Model skenario yang diperoleh berasal dari nilai rata-rata yang menunjukkan pola tracking kapal purse seine. Dengan mempertimbangkan bahwa fungsi biaya penangkapan ditentukan oleh bahan bakar, serta sediaan stok multi species (Cenek et al. 2017). Namun bukan berarti model ABM hanya untuk perikanan skala kecil, bisa juga untuk skala besar seperti longline (Yu et al. 2009) serta recreational fishing (Shafer, 2007). Model ABM yang dibanngun dari data tahun 2015-2019, diperoleh model sebaran daerah dan musim (Bailey et al. 2019) penangkapan nelayan Selat Sunda seperti pada Gambar 5.

Pada Gambar A, B, C, D, dan E merupakan model simulasi daerah penangkapan ikan yang ditandai dari tracking kapal agen (purse seine) untuk mengetahui skenario efektivitas (Bastardie et al. 2010) penangkapan. Setiap skenario dari model yang dibangun selalu menjadikan pertimbangan harga solar sebagai penentu besaran usaha perikanan. Sehingga, model ABM yang dipakai dalam penangkapan juga sebagai ilustrasi dari social-ekonomi model (Cenek et al. 2017). Dari model yang ada terlihat setiap tahunnya lokasi yang menjadi daerah penangkapan semakin mendekati fish based. Kondisi ini juga berdampak pada penurunan tingkat produktivitas usaha perikanan (Yonvitner et al. 2019). Begitu juga luasan daerah penangkapan mengalami perubahan akibat perubahan harga solar.

\section{Pembahasan}

IMP pada jenis ikan hasil tangkapan nelayan agen menunjukkan perubahan musim. Musim penangkapan berada pada musim timur dan peralihan baik peralihan 1 maupun peralihan 2 . Nelayan agen yang merupakan nelayan purse seine tidak mengenal musim penangkapan ikan melainkan fase bulan terang-gelap (lunar phase) untuk menangkap (Yonvitner et al. 2009). Pada saat fase bulan gelap nelayan agen akan melaut dan fase bulan terang tidak melaut kurang. Secara keseluruhan, masa istirahat melakukan penangkapan 5 sampai 7 hari setiap bulannya. Akyol (2013) menyatakan bahwa tingginya hasil tangkapan pada fase bulan gelap selain karena perubahan kemampuan alat (Soulie et al. 2006) melihat ikan, juga karena pengaruh lampu kapal purse seine dari ikan nocturnal pelagis. Besaran nilai IMP yang diperoleh juga dapat menunjukan waktu yang tepat dalam melakukan penangkapan ikan (Syahrir et al. 2010).
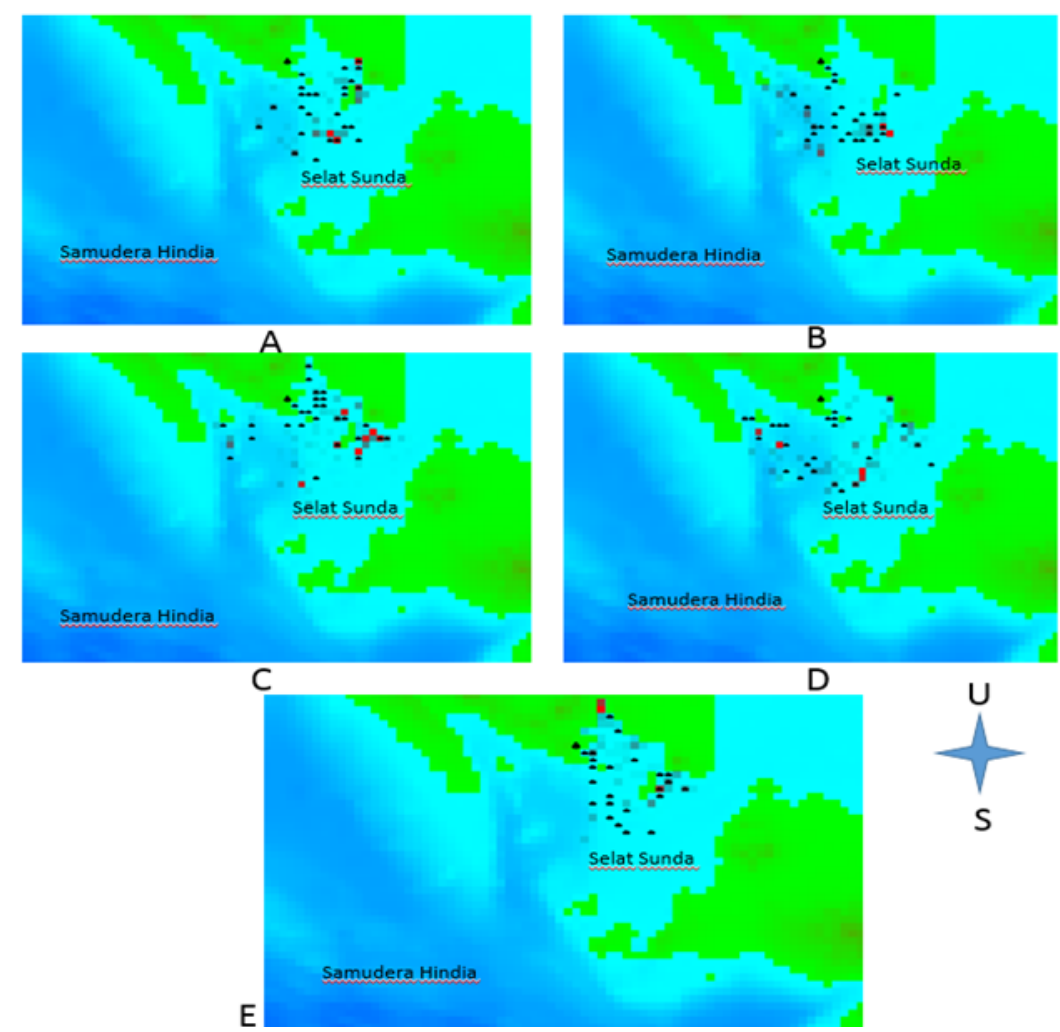

Gambar 5. Model skenario daerah penangkapan tahun 2015 (A) harga solar Rp 6.900, tahun 2016 (B) harga solar Rp 5.650, tahun 2017 (C) harga solar Rp 5.150, tahun 2018 (D) harga solar Rp 5.150 dan tahun 2019 (E) harga solar Rp. 9.800,-. 
Analisis spasial daerah fishing ground perairan sekitar Pulau Legundi yang menjadi daerah penangkapan ikan nelayan agen selain lokasi lainya (Akmal et al. 2017). Selain itu, juga menunjukkan perairan di sekitar Pulau Legundi sebagai daerah yang ekonomis dan menguntungkan (Nomura dan Yamazaki 1977) bagi nelayan Selat Sunda. Selain itu, kondisi cuaca dan musim juga dapat mempengaruhi tujuan dan daerah penangkapan. Sementara itu, Pratama et al. (2016) menyatakan penentuan daerah penangkapan alat purse seine berdasarkan musim atau arah angin. Saat musim barat, nelayan cenderung memilih daerah penangkapan pada perairan dalam yang arusnya lebih tenang dan tidak bergelombang.

Skenario pengaruh input penangkapan (harga solar) menghasilkan perubahan keputusan nelayan nelayan, perubahan daerah penangkapan, biaya operasional solar yang dikeluarkan, stok dan kuota (Little et al. 2009) sebagai input penangkapan (Elston and Cao, 2006) serta output, yaitu produksi, dan rata-rata pendapatan. Daerah penangkapan agen nelayan yang setiap waktunya hampir sama, dikarenakan keterbatasan pengetahuan tentang keberadaan fishing ground serta perairan yang tergolong subur (Salsabilla et al. 2019) serta perubahan variable lainya (Cabral et al. 2010). Namun dari model simulasi selama lima tahun, diperoleh pola tracking kapal nelayan yang cenderung selalu berada dalam wilayah perairan Selat Sunda. Kemudian pola penangkapan atau daerah penangkapan nelayan purse seine yang menjadi agent semakin lama akan mengecil atau semakin dekat dengan fish based. Fenomena ini merupakan pengaruh dari kenaikan harga solar yang terjadi setiap tahun sebagai input produksi dan produktivitas nelayan (Yonvitner 2007), efisiensi dan efektivitas penangkapan (Yonvitner et al. 2020b).

\section{KESIMPULAN}

Pendekatan agent based dapat digunakan untuk melihat keputusan nelayan dalam menentukan daerah penangkapan. Dengan input harga solar, dan produksi, maka kita dapat memperole gambaran sebaran penangkapan ikan oleh agen (nelayan). Harga solar yang meningkat, menyebabkan makin dekatnya lokasi penangkapan (fishing ground) nelayan ke lokasi pelabuhan pendaratan ikan (fishing based). Perubahan ini juga turut mempengaruhi produksi yaitu penurunan produktivitas usaha perikanan karena input produksi yang meningkat. Anomali produksi dapat terjadi ketika adanya sedian stok diperairan melimpah diperairan atau dikenal dengan puncak musim. Untuk itu agar produksi dan produktivitas dapat dikelola dengan baik, input harga bahan bakar sebaiknya dapat dikontrol dan dikendalikan.

\section{PERSANTUNAN}

Dalam kesempatan ini penulis menyampaikan ucapan terima kasih kepada Dinas Perikanan dan PPP Lempasing atas fasilitasi pesnelitian. Kemudian terhadap tim Selat Sunda Army yang selalu bekerjasama dalam menyelesaikan penelitian ini. Penelitian ini di dukungan oleh Program Hibah Penelitian dengan Nomor 4153/ IT3.L1.PN/2019 yang disiapkan oleh Kementrian Riset Teknologi dan Pendidikan Tinggi RI.

\section{DAFTAR PUSTAKA}

Akmal SG, Fahrudin A, Agus SB. 2017. Distribusi spasial kelimpahan sumberdaya ikan di Perairan Selat Sunda. Tropical Fisheries Management Journal. 1(1): 25-31.

Akyol O. 2013. The influence of the moon phase on the CPUEs of swordfish gillnet fishery in the Aegan Sea, Turkey. Turkish Journal of Fisheries and Aquatic Sciences. 13: 355-358.

An L, Linderman M, Qi J, Shortridge A, Liu J. 2005. Exploring complexity in a humanenvironment system: an agent-based spatial model for multidisciplinary and multiscale integration. Annals of the association of American geographers. 95(1): 54-79.

Ardelia V, Boer M, Yonvitner. 2017. Precautionary approach dalam pengelolaan sumberdaya ikan tongkol (Euthynnus affinis, Cantor 1849) di Perairan Selat Sunda. Tropical Fisheries Management Journal. 1 (1): 33-40.

Bastardie F, Nielsen JR, Andersen BS, Eigaard OR. 2010. Effects of fishing effort allocation scenarios on energy efficiency and profitability: an individual-based model applied to Danish fisheries. Fisheries Research. 106(3): 501-516.

Bailey RM, Carrella E, Axtell R, Burgess MG, Cabral RB, Drexler M, Saul S. 2019. A computational approach to managing coupled human-environmental systems: the POSEIDON model of ocean fisheries. Sustainability Science. 14(2): 259-275.

Cabral RB, Geronimo RC, Lim MT, Aliño PM. 2010. Effect of variable fishing strategy on fisheries under changing effort and pressure: an agent-based model application. Ecological Modelling. 221(2): 362-369.

Cenek M, Franklin M. 2017. An adaptable agentbased model for guiding multi-species Pacific salmon fisheries management within a SES framework. Ecological Modelling. 360: 132-149.

Elliston L, Cao L. 2006. An agent-based bioeconomic model of a fishery with input controls. Mathematical and computer 
modelling. 44(5-6): 565-575.

Heath BL, Hill RR. 2010. Some insights into the emergence of agent-based modelling. Journal of Simulation. 4(3): 163-169.

Little LR, Punt AE, Mapstone BD, Begg GA, GoldmanB, Williams AJ. 2009. An agentbased model for simulating trading of multispecies fisheries quota. Ecological Modelling. 220(23): 3404-3412.

Macal C, North M. 2010. Tutorial on agent-based modelling and simulation. Journal of Simulation. 4(1): 151-162.

Nomura M, Yamazaki. 1977. Fishing Techniques. Tokyo (JP): Japan Cooperation Agency.

Pratama MAD, Hapsari TD, Triarso I. 2016. Factors affecting the production of purse seine unit in fishing base Muncar Fishing Port Banyuwangi, East Java. SAINTEK PERIKANAN: Indonesian Journal of Fisheries Science and Technology. 11(2): 120 $-128$.

Pujiani R. 2009. Kondisi perikanan tangkap di Pelabuhan Perikanan Pantai Lempasing, Bandar Lampung [skripsi]. Bogor (ID): Institut Pertanian Bogor.

Rahmawan UE. 2018. Perancangan model simulasi berbasis agen untuk sistem budidaya ikan kerapu di Kecamatan Brondong, Kabupaten Lamongan [disertasi]. Surabaya (ID): Institut Teknologi Sepuluh Nopember.

Retno E. 2011. Nelayan Indonesia dalam pusaran kemiskinan struktural (perspektif sosial, ekonomi dan hukum). Perspektif. 16(3): 1-11.

Salsabila S, Affandi R. 2019. Preferensi makanan ikan kembung lelaki (Rastrelliger kanagurta Cuvier, (1816) terhadap klorofil-a. Tropical Fisheries Management Journal. 3(1): 44-50.

Saul S, Die D. 2007. Using an agent-based, object -oriented model to test the performance of catch per unit of effort as an estimator of fish abundance in small-scale, multispecies fisheries. Proceedings of the Gulf and Caribbean Fisheries Institute. 59: 267-274.

Shafer JL. 2007. Agent-based simulation of a recreational coral reef fishery: linking ecological and social dynamics [dissertation]. Manoa (US): University of Hawaii.

Simbolon D. 2010. Eksplorasi daerah penangkapan ikan cakalang melalui analisis suhu permukaan laut dan hasil tangkapan di perairan Teluk Pelabuhanratu. Jurnal Mangrove dan Pesisir. 1(2): 42-49.

Soulié JC, Thébaud O. 2006. Modeling fleet response in regulated fisheries: an agentbased approach. Mathematical and computer modelling. 44(5-6): 553-564.

Susiloningtyas D, Boer M, Adrianto L, Yulianda F. 2015. Pemodelan berbasis agen (ABM) untuk pengelolaan aktivitas migrasi musiman nelayan andon cumi-cumi di Pulau
Salura. Jurnal Sosial Ekonomi Kelautan dan Perikanan. 10(1): 103-114.

Syahrir RM, Mulyono SB, Darmawan, Ernani L, Eko SW. 2010. Pola musim penangkapan ikan pelagis di Teluk Apar. Jurnal Ilmu Perikanan Tropis. 13(1): 24-31.

Triharyuni S, Reny P. 2012. Produksi dan Musim Penagkapan Cumi-cumi (Loligo spp.) di Perairan Rembang (Jawa Tengah). Jurnal Penelitian Perikanan Indonesia. 18(2): 7783.

Waileruny W, Wiyono ES, Wisudo SH, Purbayanto A. Nurani TW. 2014. Musim dan daerah penangkapan ikan cakalang di Laut Banda dan sekitarnya Provinsi Maluku. Jurnal Teknologi Perikanan dan Kelautan. 5 (1): 41-54.

Yonvitner, Aziz KA, Butet NA, Pujiastui D. 2009. Lunar moon phase terhadap tangkapan persatuan upaya ikan kembung (Rastrelliger sp) Di Pulau Damar, Kepulauan Seribu. Jurnal Perikanan dan Kelautan. 14 (1): 70-80.

Yonvitner, Boer M, Akmal SG, Andi IS. 2018. Kerentanan intrinsik dan risiko pemanfaatan perikanan: analisis berbasis data poor untuk pengelolaan berkelanjutan. Tropical Fisheries Management Journal. 2(2): 54-60.

Yonvitner. 2007. Produktivitas nelayan, kapal dan alat tangkap di Wilayah Pengelolaan Perikanan Indonesia. Jurnal Perikanan Universitas Gadjah Mada. 9(2): 254-266.

Yonvitner, Yuliana E, Yani DE, Setijorini LE, Santoso A, Boer M, Kurnia R, Akmal S G. 2020. Fishing gear productivity related fishing intensity and potency of stock vulnerability in Sunda strait. In $I O P$ Conference Series: Earth and Environmental Science. 404: 012066.

Yonvitner, Boer M, Kurnia R. 2020b. Kajian tingkat efektifitas perikanan untuk pengembangan secara berkelanjutan di Provinsi Banten. Jurnal Kebijakan Perikanan Indonesia. 12(1): 35-46.

Yu R, Pan M, Railsback SF, Leung P. 2009. A prototype agent based fishery management model of Hawaii's Longline Fishery. In: Anderssen RS, Braddock RD, Newham LTH (eds). 18th World IMACS Congress and MODSIM09 International Congress on Modelling and Simulation.

Zulkarnain, Wahju RI, Sulistiono. 2012. Komposisi dan estimasi musim penangkapan ikan pelagis kecil dari purse seine yang didaratkan di PPN Pekalongan, Jawa Tengah. Jurnal Saintek Perikanan. 7(2): 61-70. 